\title{
Saving for Stability
}

Countries invest in physical capital in order to grow. In principle, domestic investment can be financed with either national or foreign financing. However, foreign financing is not a good substitute for national financing. To begin with, it may not be available. Moreover, it is generally more expensive or more uncertain, or both. Consequently, the scarcity of national saving to finance good investment opportunities is a constraint to growth.

Besides investment, foreign financing is also a poor substitute for national financing in terms of macroeconomic stability. National and foreign savings are different in that absorbing capital inflows risks destabilizing external accounts, which can lead to costly macroeconomic crises. ' Crisis-related volatility-which unfortunately has plagued many Latin American and Caribbean countries-in turn discourages saving in domestic assets because the real value of savings usually falls in the aftermath of financial crises. It also discourages foreign investors from committing resources to the domestic economy, which jacks up the cost premium for external capital. This sets in motion a vicious circle of low national saving, higher demand for foreign saving (which is less forthcoming), increased sovereign risk, macroeconomic crises, and so on. Mobilizing national saving would thus help break the circle and set in motion the opposite, and positive, dynamic.

\section{Foreign Financing: A Different Animal}

Foreign and national financing are simply not the same. If foreign and national financing were two sides of the same coin, countries could substitute one for the other with ease. A world with such perfect financial integration across countries would look entirely different. National savers would prefer to stash most of their wealth in foreign assets in order 
to hedge the fluctuations of their domestic sources of income. This financial incentive for portfolio diversification would lead to domestic investment being mainly funded by foreign financing. But this imaginary world doesn't exist. In the real world, foreign saving is small relative to the volume of domestic investment, and the financing of the domestic capital stock in each country is predominantly national. ${ }^{2}$

The underlying reason for this poor substitution is that foreign financing is simply a different animal. It carries an additional risk premium - the so-called country risk spread-because each sovereign state retains jurisdiction to rule in favor of nationals. Even with relatively little foreign exposure, when a country's economic prospects deteriorate, the risk premium may spike and eventually become prohibitive. This is hardly surprising: foreigners tend to know less about local conditions and may be more vulnerable than domestic investors to, for example, the risk of expropriation. Why would foreigners want to invest in countries where locals are not eager to save more, in the absence of a premium to entice them?

In the absence of country risk spread, the supply of foreign financing would be totally elastic at the international interest rate. Any shortfall of national financing could be seamlessly replaced by additional foreign financing, thereby keeping investment unchanged. ${ }^{3}$ However, because there is a foreign risk premium, national financing is cheaper and it therefore supports more investment. ${ }^{4}$

National savings may also attract better foreign financing. Aghion, Comin, and Howitt (2006) explain how national financing is a form of collateral that entices foreign savers to participate in domestic investment. They need that collateral as an incentive to invest because they know less about local conditions than local investors. Their lack of knowledge is a so-called agency problem. Without the collateral in the form of national financing, foreign financing of local projects would be slim indeed; as a result, investment would be even more constrained.

Because foreign financing is different, domestic investment and national saving are highly correlated across countries (see Feldstein and Horioka [1980] and Chapter 4)..$^{5}$ The "home bias" captured by Feldstein-Horioka-type estimates around the world is also verified in Latin America and the Caribbean (Cavallo and Pedemonte, 2015). A positive correlation between domestic investment and national saving is the natural consequence of de facto imperfect financial integration across countries, where shocks to national saving would directly impact 
investment because they would not be completely offset by foreign saving. Foreign saving can help fill gaps in investment, but it cannot cure weak national saving.

For all these reasons, strong national saving is important for strong investment. This chapter goes beyond this point and will show that foreign saving is not only a poor substitute for national saving for investment purposes but also in terms of macroeconomic risk. In contrast to national saving, foreign saving contributes to the risk of an external crisis, that is, a crisis in the balance of payments. Low national saving not only constrains real investment but may also create financial vulnerabilities associated with external crises.

\section{Risky Business: Absorbing Foreign Saving}

Countries in Latin America and the Caribbean exhibit low national saving rates and absorb more foreign savings (as a share of their national product), on average, than those, for example, in East Asia (see Chapter 2). There are reasons to suspect that foreign savings may contribute to building up risks that may evolve into macroeconomic crises, and the ensuing volatility associated with these crises.

First, foreign financing may be unreliable because its availability and financial terms depend on changing international circumstances that are beyond the control of national authorities. Capital flows to Latin America and the Caribbean are influenced by external factors (the so-called "push factors"). ${ }^{6}$ For example, events such as the U.S. Federal Reserve Board's decision to raise interest rates may significantly impede capital inflows to the region.

Second, foreign financiers may be especially anxious because they rightly fear that under economic stress, national policies may discriminate against foreign liabilities or even expropriate them as a quick way to favor national welfare-especially if foreign liabilities become too large relative to the size of the domestic economy. In those contexts, foreign investors may understandably want to limit their exposure to a country and, if they decide to run the risk, favor capital flows that are short term, liquid, and easier to repatriate. This behavior, in turn, would lead to procyclical capital flows during crisis periods that undermine macroeconomic stability.

Third, to attract foreign financing, investments must offer high returns in foreign currency, which requires the host country to be capable 
of generating foreign exchange. Again, foreign and national savings are different. In most cases, external debt contracts are stipulated in foreign currency and need to be serviced correspondingly. The inability to issue foreign debt in local currency at reasonable terms-the so-called "original sin" of emerging economies-still dogs the region and hampers financial integration (see Levy Yeyati and Zúñiga, 2015). More generally, regardless of the specifics of the foreign liability contract, in the final analysis, foreigners care about the real value of their holdings in terms of their purchasing power in their own countries. For example, U.S. holders of equity assets, either of national or foreign companies, care about the dollar value of their shares. This means that foreigners care about the potential conversion of domestic assets into foreign currency. In the absence of disposable foreign assets, the ability of a country to generate foreign exchange may be limited. In fact, transforming domestic resources into foreign exchange by increasing net exports is a disruptive and costly process, especially if it has to be done quickly.

Unreliable foreign savings and difficult balance of payments adjustments make for an explosive mix, which can often end in a macroeconomic crisis. Therefore, while more foreign savings helps in filling the gap left by limited national saving and relieving the constraint on domestic investment, it carries serious financial risks (Rancière, Tornell, and Westerman, 2006). In a worst case scenario, the macroeconomic risks of accumulating too many foreign liabilities over time may incur not only direct crisis costs, but may raise the cost of capital and ultimately depress investment. ${ }^{7}$

By contrast, by reducing reliance on foreign saving, stronger national saving is positive on both counts: it not only helps raise investment but also lowers macroeconomic risks. Each factor reinforces the other, thereby contributing to faster and less volatile growth.

Can the market be trusted to adequately balance foreign savings with macroeconomic risk? Possibly not. Firms that turn to foreign financing may not adequately weigh their needs against the collective harm of contributing to mounting aggregate foreign financing that may upset macroeconomic equilibrium. By raising macroeconomic risk, each addition to foreign liabilities compromises the net returns of aggregate investment without facing any disincentive to do so at the firm level. ${ }^{8}$ Furthermore, the true measure of macroeconomic risk may actually exceed what is reflected in financial market pricing (such as sovereign spreads or yields on credit-default swaps): much of the cost of crises is 
often ultimately borne by workers and other third parties (including taxpayers) not involved in the financial transactions. The bottom line is that the market may fail to find the right trade-off between economic risk and return on foreign saving. If so, this market failure provides a rationale for public policy to promote national saving. ${ }^{9}$

Does the use of foreign saving increase crisis risk in practice? Countries vary widely in their rates of absorbing foreign saving over time and, therefore, in their net foreign liabilities positions-that is, the sum of foreign liabilities minus foreign assets (Lane and Milesi-Ferretti, 2007). This is because the net foreign liabilities position of a country is the sum of its accumulated foreign saving, appropriately priced and depreciated over time. Catão and Milesi-Ferretti (2014) show that a country's ratio of net foreign liabilities to GDP performs well as a predictor of external crises. ${ }^{10}$ Their definition of external crisis includes major episodes that affect the domestic economy, for example, sovereign debt defaults and rescheduling events, as well as events associated with significant support by the International Monetary Fund (IMF). ${ }^{11}$ These crises, in turn, are usually associated with a drop in output and other economic, social, and political costs. ${ }^{12}$

Figure 5.1 shows the proportion of countries in Latin America and the Caribbean, and in the rest of the world, that entered into an external crisis in a given year. ${ }^{13}$ In the early 1980s, most countries in Latin

\section{Figure 5.1 Proportion of Countries Entering into External Crisis}

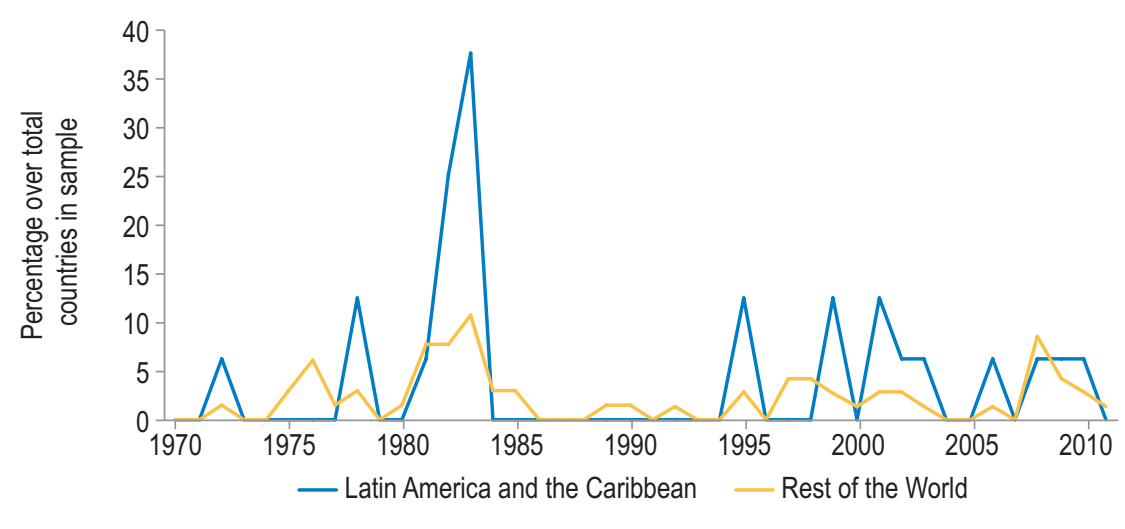

Source: Authors' calculations based on the definition of "external crisis" in Catão and Milesi-Ferretti (2014).

Note: The figure shows the proportion of countries in Latin America and the Caribbean, and in the rest of the world, entering an external crisis in a given year. The data shows some bunching over time; that is, external crises affect multiple countries at the same time. 
Figure 5.2 Net Foreign Liabilities Positions

Simple Average by Country Group

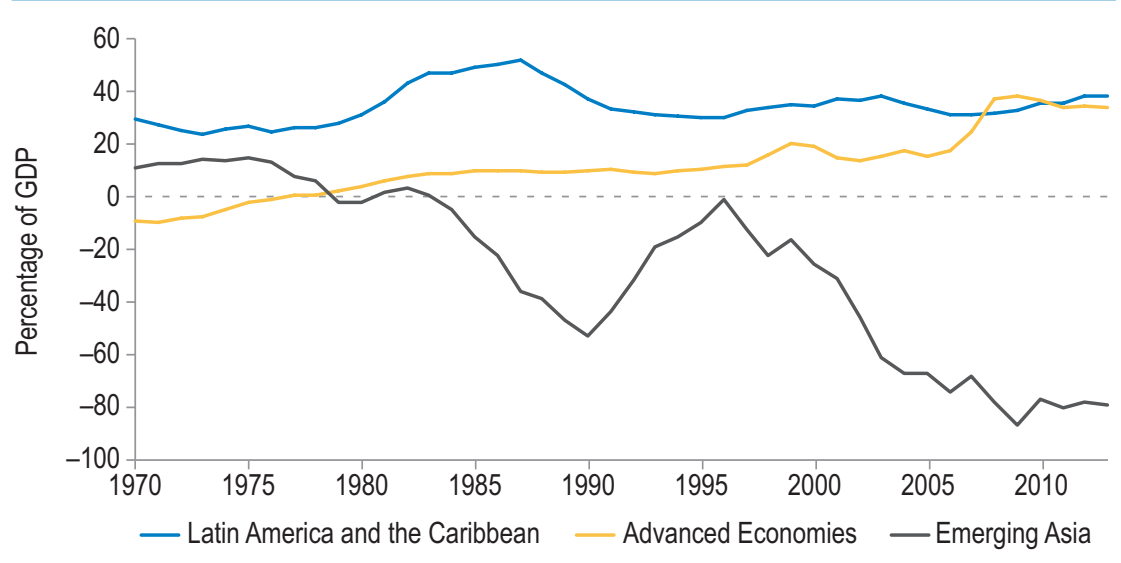

Source: Authors' calculations based on External Wealth of Nations database.

Note: Figure shows the simple average of Net Foreign Liabilities (as a percent of GDP) for select country groupings. See endnote 3 in chapter 2 for the list of countries in each country group.

America and the Caribbean suffered an external crisis. Other volatile periods included the mid-1990s (the "Tequila Crisis," which originated in Mexico and spread throughout the region); the late 1990s through the early 2000s (the aftermath of the Asian and Russian financial crises of 1997 and 1998); and the period following the global financial crisis of 2008. Compared to the rest of the world, Latin America and the Caribbean is clearly a region of high risk. ${ }^{14}$

According to Catão and Milesi-Ferretti (2014), the high risk in this region can in turn be traced to its large net foreign liabilities position (measured as share of GDP). Figure 5.2 shows that the typical Latin American and Caribbean country has a larger net foreign liabilities position (relative to GDP) than the typical country in other regions. The contrast is striking vis-à-vis Emerging Asia, where the typical country is a large net creditor.

The pattern of high net foreign liabilities is especially relevant for the smaller countries in the region, many of which are located in Central American and Caribbean (see Figure 5.3). Net foreign liabilities (as a share of GDP) have been increasing over the last decade in the typical country in the group of smaller countries. By contrast, the same ratio has been declining for the typical country in the group of largest economies in the region (the so-called "LAC-7" of Argentina, Brazil, Chile, Colombia, Mexico, Peru, and Venezuela). 
Figure 5.3 Net Foreign Liabilities Positions in Latin America and the Caribbean Simple Average by Country Group

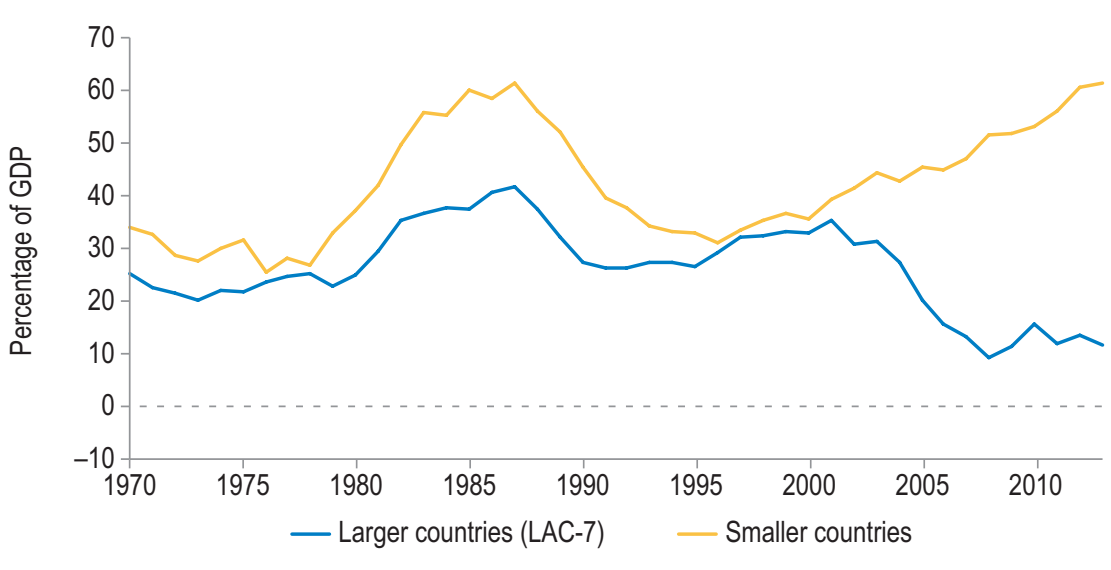

Source: Authors' calculations based on External Wealth of Nations database.

Note: The figure shows the simple average of Net Foreign Liabilities (as a percent of GDP) for select country groupings. LAC-7 includes Argentina, Brazil, Chile, Colombia, Mexico, Peru, and Venezuela. Together, they account for more than 90 percent of the regional GDP. Smaller countries are the rest of the countries in the region not included in LAC-7, most of them in Central America and the Caribbean.

Can the risks of crisis be reduced by financing domestic investment with national savings instead of foreign savings? In other words, is national saving better in terms of associated macroeconomic risks? Cavallo, Fernández-Arias, and Marzani (2016) expanded Catão and Milesi-Ferretti's statistical analysis to include the so-called self-financed capital stock (i.e., the sum of accumulated national saving, appropriately depreciated over time) as an additional explanatory variable for external crises in the regressions. The self-financed capital stock provides a stock measure of the portion of domestic investment that is covered by national saving; it is the domestic capital stock for which financing did not rely on foreign saving. By construction, the self-financed capital stock is the "national" counterpart to the net foreign liability position of a country. ${ }^{15}$ Therefore, introducing the self-financed capital stock simultaneously with the net foreign liability (both measured as ratios of GDP) in the regressions allows for assessing the relative contribution of each to building up external risks.

The results confirm that net foreign liabilities (which is accumulated foreign saving) remain a significant predictor of external crises, while the self-financed capital stock carries much less risk, or no risk at all. ${ }^{16}$ Changing the composition of investment financing in favor of national saving would reduce the risk of external crises. In fact, given the large 
difference in the estimated risk coefficients, increasing national savings would lessen risk even if foreign savings are reduced only marginally. ${ }^{17}$ National saving is thus a safer source of investment financing.

\section{Not All Foreign Saving Is Created Equal}

Economists refer to foreign saving as the net flow of capital into a country. Therefore, countries running current account deficits (where investment exceeds national saving) are net importers of saving, while countries running current account surpluses are net exporters of saving. Yet the net flow itself is a combination of two elements: "gross capital inflows" to the reporting economy from foreign savers minus "gross capital outflows" from the reporting economy by national savers. The latter is national saving that is used to acquire foreign assets. Specifically, whenever a resident purchases a foreign asset, that transaction-all else equal-reduces foreign saving in the country where the transaction originated. If this is not made up by a gross capital inflow (that is, a financial transaction in the opposite direction), less aggregate financing will be available for domestic investment. What implications-if any-do these two-way financial transactions have on external crisis risk? Is it only the net foreign liabilities (the absorption of capital inflows net of capital outflows) that really matter for macroeconomic risk? Or, instead, do gross inflows and outflows contribute differently to risk?

The arguments concerning poor substitutability between financing sources focus on the weaker position of foreigners with respect to nationals and the potential difficulties in generating the foreign exchange that foreigners care about. This argument demands looking at gross-rather than net-positions, differentiating gross liabilities (which result from the accumulation of capital inflows from foreigners) from gross assets (which result from the accumulation of capital outflows from nationals). ${ }^{18}$

Gross foreign liabilities are likely to be risky because they require a premium to leave the home country and may be unreliable (volatile) as a source of financing. How about gross foreign assets? National saving used to purchase foreign assets-sometimes referred to as capital flight-is presumed to be inconsequential for risk because these assets are placed outside the domestic economy. However, they can also be a safety net for nationals if they can be used to stabilize shocks when foreign financing dries up. In particular, residents can repatriate accumulated foreign assets to offset a sudden stop in gross capital inflows. ${ }^{19}$ 
Figure 5.4 Gross Foreign Assets and Liabilities around the World

Simple Average by Country Group

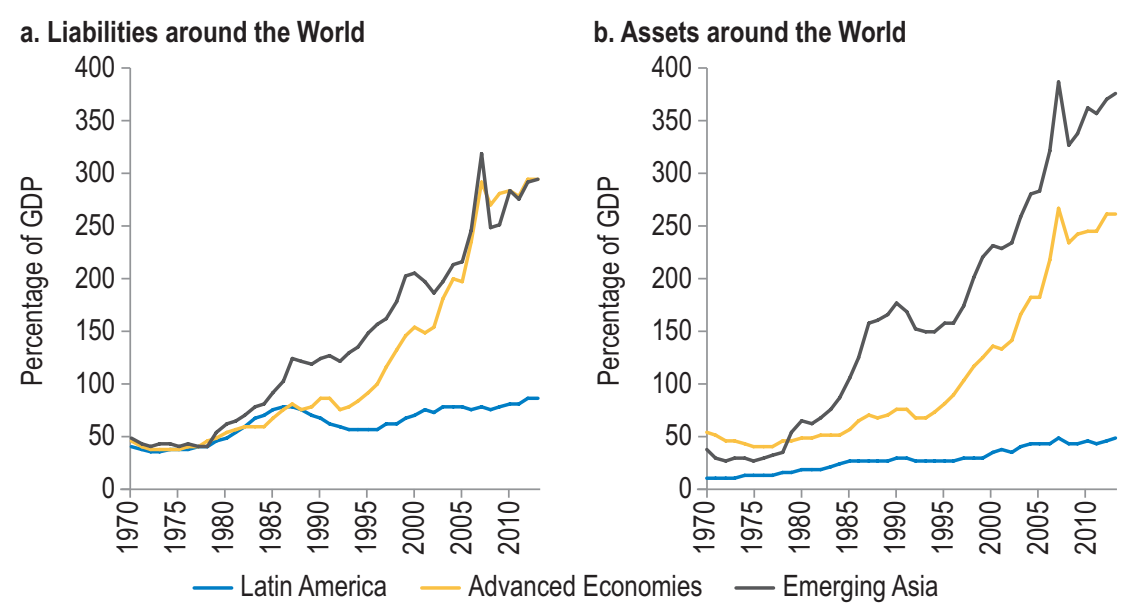

c. Liabilities in Latin America and the Caribbean

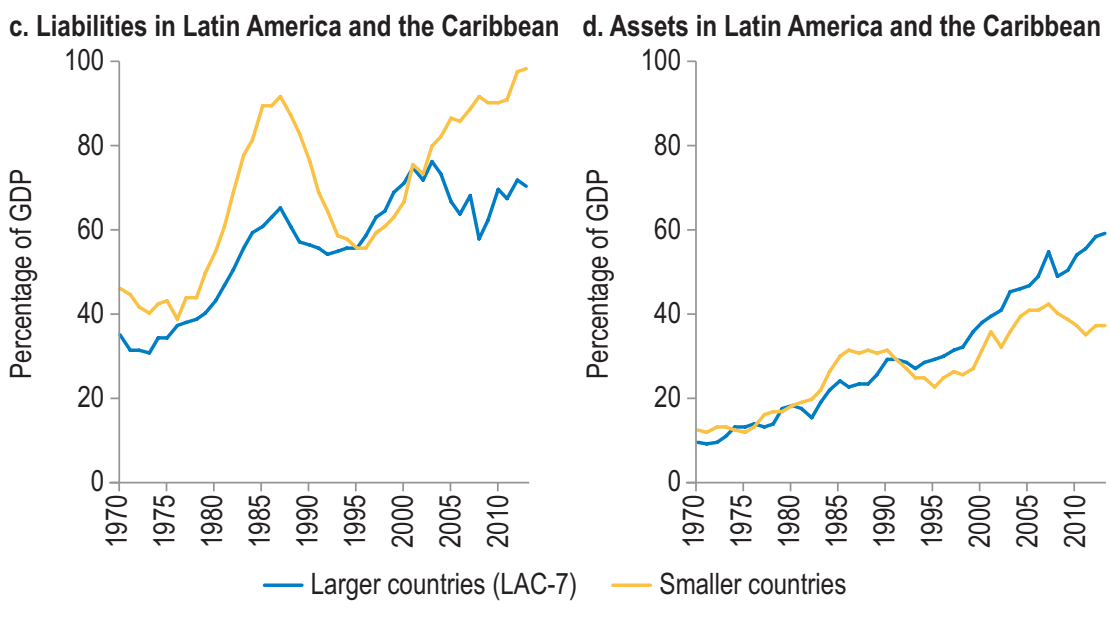

Source: Authors' calculations based on the External Wealth of Nations database.

Note: The figure shows the simple average of gross foreign liabilities and assets (as percentage of GDP) for select country groupings. See endnote 3 in chapter 2 and note on figure 5.3. for the list of countries in each country group.

At the same time, capital flight would contribute to risk by indirectly reducing available funding and creating the need to absorb more gross capital inflows to finance any given domestic investment. The net effect would depend on whether the protective effect of foreign assets more than offsets the risk effect of higher foreign liabilities.

Over the last decade or so, both gross capital inflows and outflows have increased significantly. Figure 5.4 tracks the resulting gross foreign 
liabilities and assets in the typical country in select regions of the world. In Advanced Economies and in Emerging Asia, gross foreign assets and liabilities have risen remarkably to approximately 300 percent of GDP. In Latin America and the Caribbean, the trend is similar but well below the other two groups of countries.

These trends of increasing gross assets and liabilities are likely the result of deeper financial integration, which has facilitated cross-border financial transactions to diversify portfolios and share international risks. ${ }^{20}$ The corollary of this process is that, in many countries, including in Latin American and the Caribbean, net foreign liabilities are now underpinned by more substantial gross external assets and liabilities (see Figure 5.5).

To analyze the implications of gross positions for the risk of external crises, the effect of foreign liabilities and assets were examined separately using the same empirical model as in the preceding section (see Cavallo, Fernández-Arias, and Marzani, 2016). The net foreign liabilities were replaced by the gross components (i.e., total foreign liabilities and total foreign assets respectively, both as ratios of GDP) in the regressions; ${ }^{21}$ the other explanatory variables (including the self-financed capital stock) were left unchanged. The results confirm that gross foreign liabilities increase the probability of crisis. At the same time, foreign

\section{Figure 5.5 Gross Foreign Assets and Liabilities}

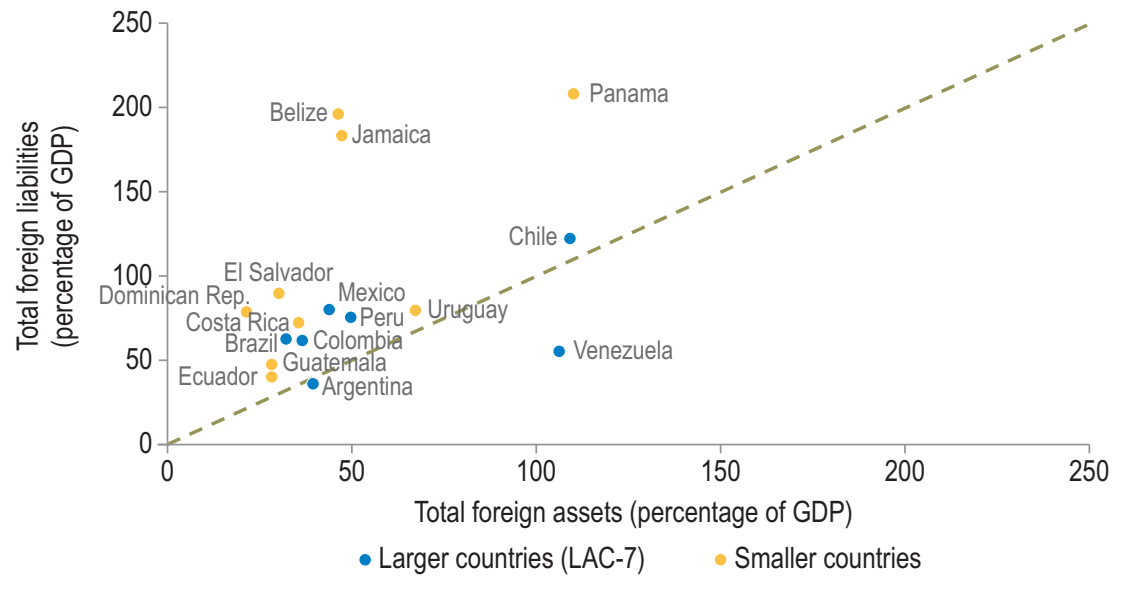

Source: Authors' calculations based on External Wealth of Nations database.

Note: The figure shows the simple average of total foreign assets and liabilities (as a percent of GDP) for select country groupings in 2013 . At the $45^{\circ}$ line, total foreign assets equal total foreign liabilities: that is, net foreign liabilities (NFL) equal zero. Dots above the $45^{\circ}$ line depict countries with NFL $>0$. Dots below the $45^{\circ}$ line depict countries with $\mathrm{NFL}<0$. 
assets appear to reduce the risk of crisis, suggesting that foreign assets do serve as insurance because they can be repatriated. This last finding contradicts the popular view that what really matters for risk is gross foreign liabilities and that capital outflows are irrelevant. Of course, higher capital outflows can be expected to go hand in hand with additional capital inflows needed to satisfy domestic investment demand-a natural consequence of better international financial integration that allows inflows and outflows to grow in tandem (see Borio and Disyatat, 2011). So it is important to gauge the extent to which the protection afforded by foreign assets mitigates the risk brought by foreign liabilities. Based on the coefficient estimates on foreign assets and liabilities respectively, a dollar of foreign assets appears to more than offset the risk generated by a dollar of foreign liabilities. ${ }^{22}$ Thus, the net position of foreign liabilities is not sufficient to predict the risk of external crises. The underlying gross positions are also important: a given net position is less risky if it is supported by deeper financial integration (i.e., more gross foreign assets and liabilities).

Finally, it is important to note that in the expanded regressions, the self-financed capital stock (i.e., the accumulated national saving) continues to carry little or no risk. This in turn implies that more national saving in order to lower the dependence on foreign saving for investment would reduce macroeconomic risk. If the absorption of less foreign saving takes the form of fewer foreign liabilities, some of the risk would be removed. If it takes the form of more foreign assets, some of the risk would be mitigated. All told, stronger national saving is the key to increasing investment at minimum risk.

\section{Different Risks for Different Financial Flows}

Different types of foreign financial flows may pose different risks to the domestic economy. If so, assessing macroeconomic risk by looking at aggregates, even if discriminating between gross foreign assets and liabilities, paints a misleading picture. In particular, countries with riskier types of foreign liabilities would underestimate the macroeconomic risk of foreign financing.

Liabilities are often differentiated by characteristics such as the international risk sharing they provide and how volatile they are. A pecking order of foreign liabilities might consider short-term debt in foreign currency the riskiest and foreign direct investment the safest. ${ }^{23}$ The 
key point is that different types of capital inflows may impact country solvency differently (both the ability and willingness to honor foreign claims) and the liquidity the country needs for macroeconomic stability. There is much less research on how different types of foreign assets may help prevent macroeconomic crises or cure their effects. However, it stands to reason that how easy it is to repatriate assets and how effectively they can be channeled by the financial system to address the sources of financial stress are key for their insurance value. ${ }^{24}$

Distinguishing foreign assets and liabilities by type may be relevant for both the risk potential of foreign liabilities and the safety value of foreign assets because portfolio composition varies across countries. In order to study the countries' risk profile in a more granular fashion, the same empirical model of the preceding sections was used. In this case, however, gross foreign liabilities and assets were decomposed into their main components. For this purpose, total foreign liabilities are disaggregated into three types of stocks: debt, portfolio equity investment, and direct equity investment. In the case of total foreign assets, the decomposition also includes foreign exchange reserves held by the public sector as a separate category on top of this three way classification.

The results show that the type of financial flow matters. On the liabilities side, the finding is that external crisis risk rises as the composition of gross foreign liabilities tilts toward debt instruments. Statistical evidence suggests that equity instruments (both portfolio and direct investment) are relatively low risk compared to debt. In particular, foreign direct investment is less risky than debt. ${ }^{25}$ Still, in the expanded regressions, the risk associated with self-financed capital stock remains negligible compared to the risk associated with foreign debt liabilities.

On the assets side, foreign assets that can be more easily sold (portfolio equity assets, reserve assets, and debt assets) reduce the risk of external crises. By contrast, foreign direct investment (FDI), the least liquid of the four, has no such insurance value. Once again, the types of asset that are more easily repatriated carry an insurance value. In particular, reserve assets, which are designed to protect external equilibrium, appear in fact to be useful to prevent crises.

Thus, the risks associated with net foreign liabilities vary with the financial characteristics of international financing-mainly the debt/ equity divide of foreign liabilities and the degree of liquidity of foreign assets. Therefore, fully assessing the risks of using foreign saving 
to supplement national saving requires taking into account the composition of the resulting portfolio of foreign assets and liabilities. Put differently, what is gained in stability by strengthening national saving depends on how the portfolio of net foreign saving would shrink.

Given these differential risk features, it is reassuring that the composition of assets and liabilities in Latin America and the Caribbean has been changing for the better since the 1990s (Figures 5.6 and 5.7). The most remarkable trend in the region is the increase in the share of equity among foreign liabilities, especially foreign direct investment, and the corresponding decline in the share of debt. On the foreign assets side,

\section{Figure 5.6 Composition of Gross Foreign Liabilities}

Simple Average by Country Group

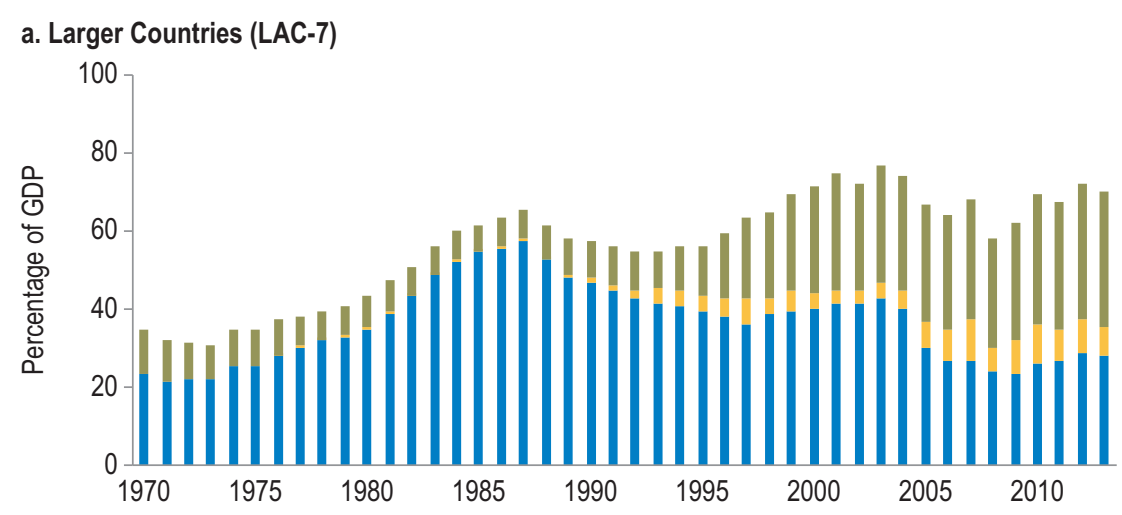

b. Smaller Countries

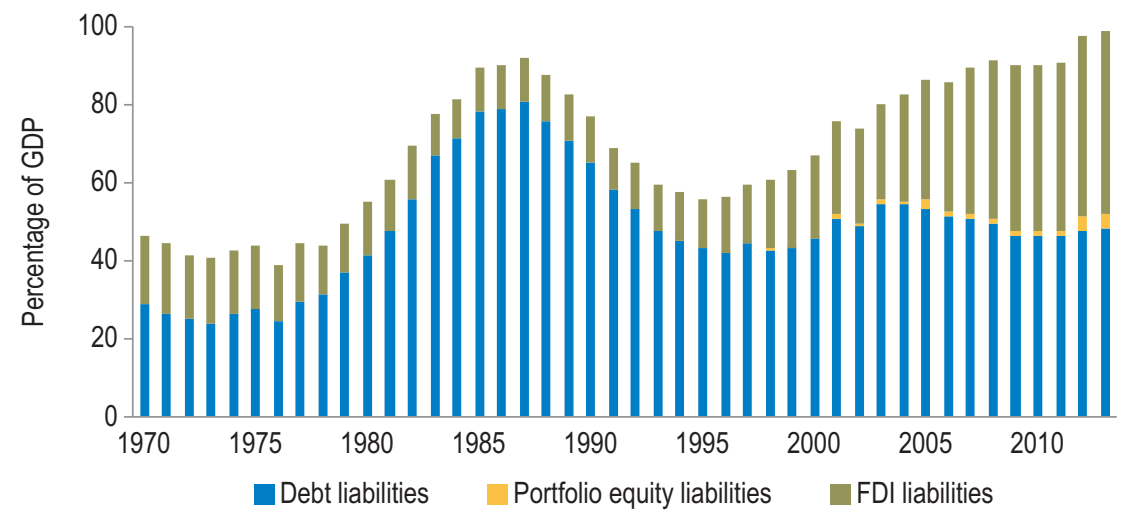

Source: Authors' calculations based on External Wealth of Nations database.

Note: The figure shows the composition of foreign liabilities by instrument. Simple averages by country group are presented. Financial derivatives, which are small in Latin America and the Caribbean, are not shown in this decomposition. FDI = foreign direct investment. For country groupings see note on Figure 5.3. 
Figure 5.7 Composition of Gross Foreign Assets

Simple Average by Country Group

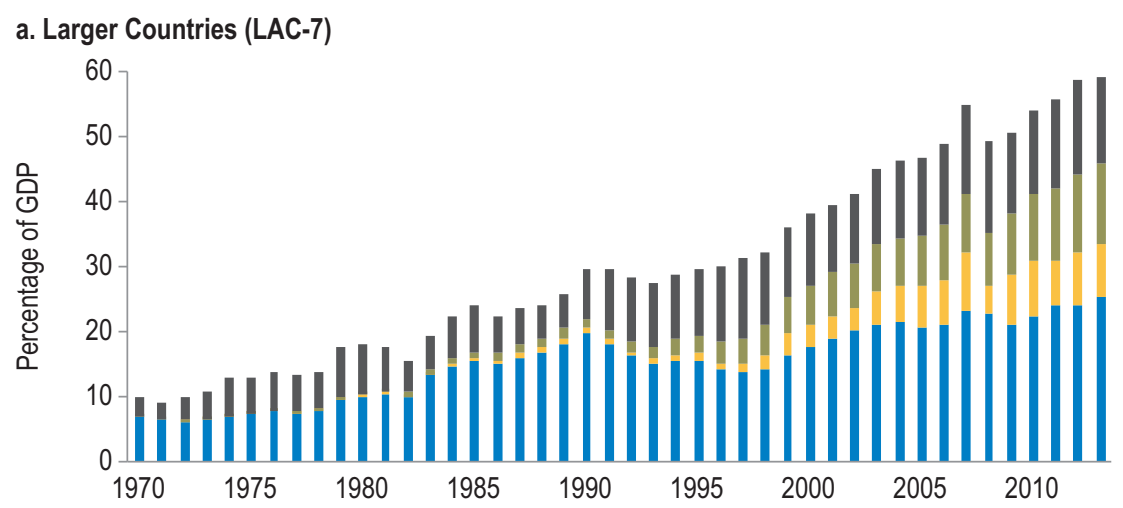

b. Smaller Countries

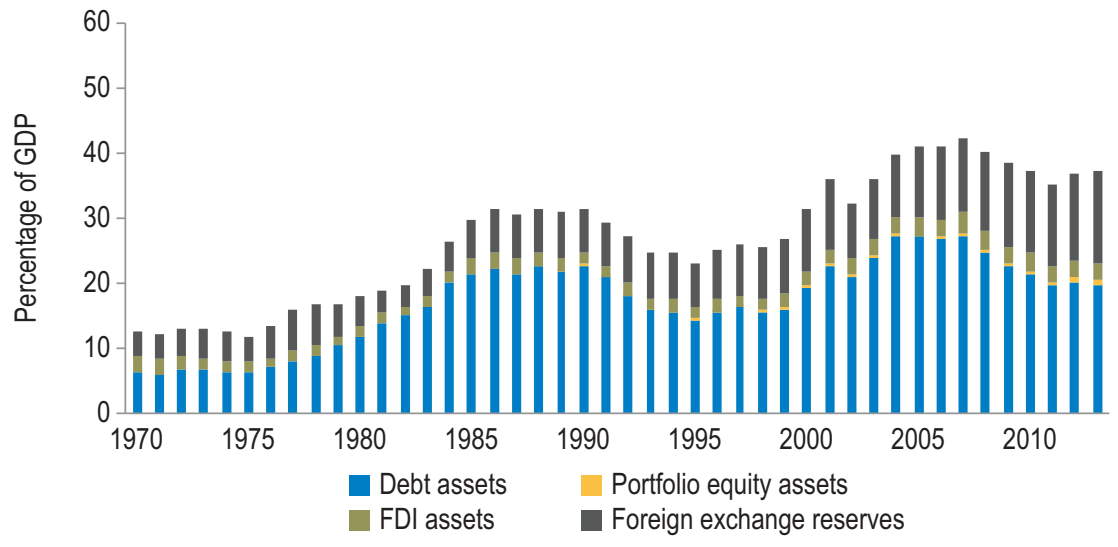

Source: Authors' calculations based on External Wealth of Nations database.

Note: The figure shows the composition of foreign liabilities by instrument. Simple averages by country group are presented. Financial derivatives, which are small in Latin America and the Caribbean, are not shown in this decomposition. FDI = foreign direct investment. For country groupings see note on Figure 5.3.

reserve assets have increased significantly among both large and small countries in the region while portfolio and direct equity investment assets have also risen considerably among the larger countries.

Cavallo, Fernández-Arias, and Marzani (2016) use the model described earlier to obtain a risk profile of foreign savings that depends on the portfolio composition of foreign assets and liabilities in a country's balance sheet. Their External Portfolio Vulnerability Index (EPVI) sums up how each country's portfolio item contributes to the risk of an external crisis and is normalized such that values higher than 1 indicate 
Figure 5.8 External Portfolio Vulnerability Index (EPVI)

Simple Average by Country Group

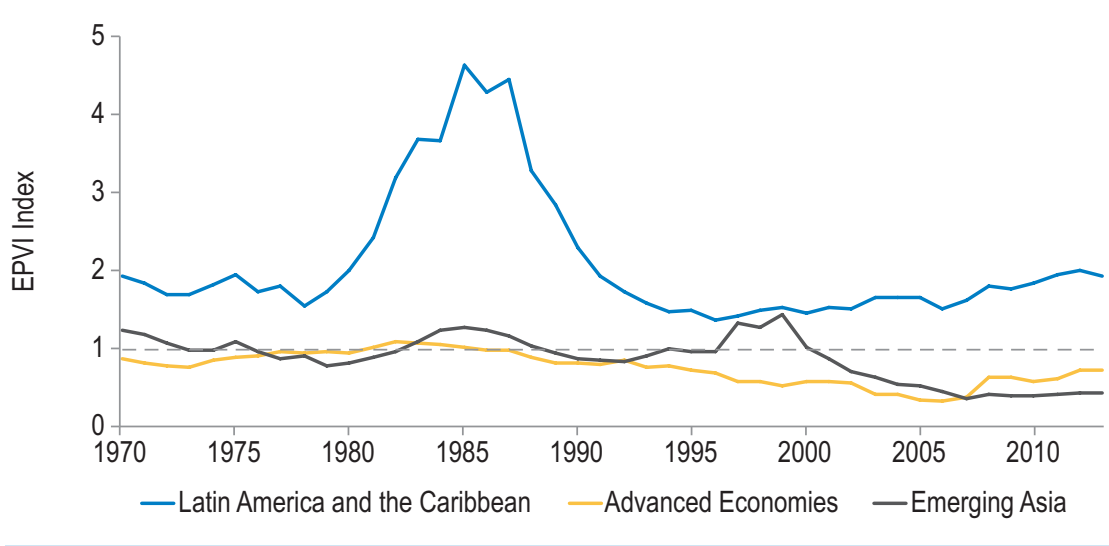

Source: Authors' elaboration based on Cavallo, Fernández-Arias, and Marzani (2016).

Note: The External Portfolio Vulnerability Index (EPVI) is the exponential of the linear combination of the observed values of the variables related to the external portfolio (gross foreign assets and liabilities) with the estimated coefficients in the probit regression acting as coefficients. Values of the EPVI higher than 1 indicate the portfolio by itself increases the probability of an external crisis. The figure presents the simple average by region. See endnote 3 in Chapter 2 for the list of countries in each country group.

that the external portfolio is a risk factor (it increases the probability of an external crisis) and values lower than 1 mean that the portfolio is a risk mitigating factor (it reduces the probability of an external crisis). ${ }^{26}$

In Latin America and the Caribbean, the external portfolio in the 1980s was clearly very risky (see Figure 5.8). From the end of that decade to the mid-1990s, the index declined rapidly. However, since then, it has been creeping up again as net foreign liabilities have been rising, on average. The EPVI for the typical country in the region is still above the neutral level, meaning that on average the portfolio of foreign liabilities and assets is still a risk factor for external crisis. In sharp contrast, in Emerging Asia, countries' external portfolios help reduce the risks of external crisis.

The bottom line is that the gradual shift to safer foreign assets and liabilities has helped lower the risk posed by the external portfolio. However, despite this improvement, the risk associated with the external portfolio in Latin America and the Caribbean has been on the rise for several years and remains high by international standards. As discussed earlier, stronger national saving would help reduce the risk (assuming that investment increases less than national saving, as the evidence indicates), either by lowering demand for foreign liabilities or by facilitating 
the accumulation of foreign assets. Therefore, countries in which liabilities are riskier and assets are safer would benefit the most from stronger national saving. As foreign portfolios become safer, the effectiveness of stronger national saving crucially depends on whether the offset foreign saving takes the form of less liabilities or more assets. On the margin, risk reduction is maximized when additional national savings are channeled to strengthen foreign assets. In that case, a safer composition of the external portfolio strengthens the case for more national saving as a means to reduce risk.

\section{Financial Integration Is No Cure}

Better financial integration can facilitate the flow of financial capital across countries. Consequently, it can alleviate the negative impact of a national saving shortfall and sustain higher domestic investment with a low cost of capital. ${ }^{27}$ However, if financial integration ushers in too much foreign financing (particularly risky forms), it can also jack up the risk of external crises. ${ }^{28}$ In turn, if costly crises occur more frequently, financial integration could even deter investment down the road. Moreover, open capital accounts may conceivably reduce, rather than expand, the pool of national saving available for domestic investment. In countries where domestic conditions do not nurture national saving-such as inflationary environments, or institutional environments that offer little protection of property rights-savers may choose to place their saving abroad, thereby reducing the pool of national saving for financing domestic investment. Opening capital accounts without providing the correct incentives for local savers can facilitate capital flight, further constraining domestic investment in countries with little access to foreign financing.

The first sign that Latin America and the Caribbean should not pin too much hope on international financial integration as a cure-all is the evolution of the so-called "self-financing ratio" of the domestic capital stock, which does not appear to be declining over time (See Figure 5.9). The self-financing ratio is the ratio of the self-financed capital stock (i.e., the accumulated national saving, appropriately discounted) to the total domestic capital stock (see Aizenman, Pinto, and Radziwill, 2007). The flipside of the high importance of national saving as the main source for investment financing is the low importance of foreign saving in building capital stock. True, some national savings do not finance domestic investment but leak abroad as capital outflows, meaning the amount of 
Figure 5.9 Self-Financing Ratio

Simple Average

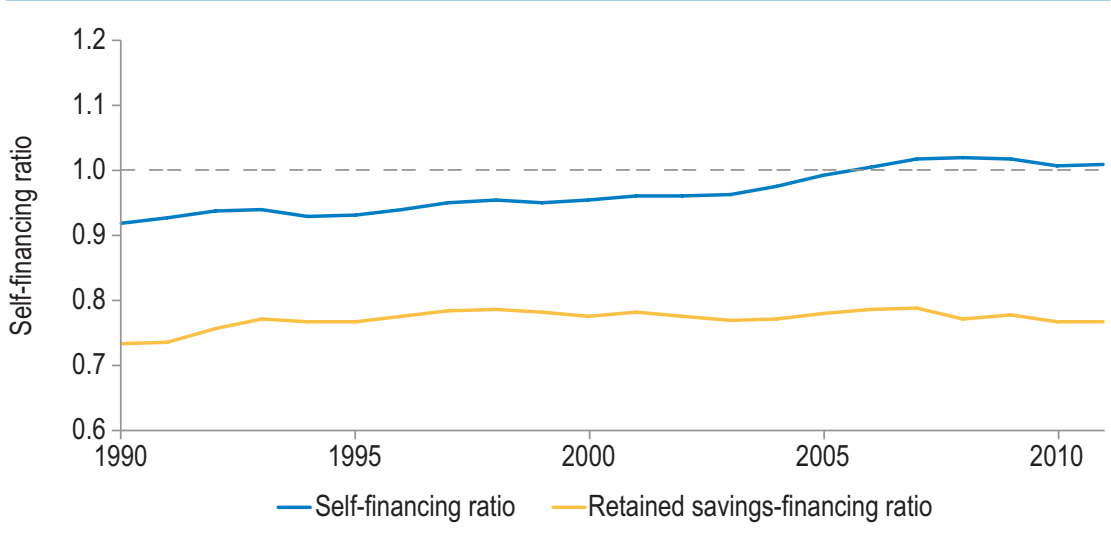

Source: Authors' calculations based on data from World Bank World Development Indicators database based on methodology developed by Aizenman, Pinto and Radziwill (2007), extended on Cavallo, Fernández-Arias and Marzani (2016).

Note: The figure shows the regional simple average for the self-financing ratio (SFR), and a version of the SFR in which gross outflows are deducted from gross national saving in the numerator of the formula. This is the so-called retained savings-financing ratio.

investment financed from abroad is larger than what (net) foreign saving suggests. Nevertheless, even if all the capital outflows are subtracted, which yields a lower bound for national financing, the high importance of accumulated national saving does not appear to be declining over time (Figure 5.9).

To calculate the possible impact of increased financial integration on domestic investment, Cavallo, Fernández-Arias, and Marzani (2016) extend the basic Feldstein and Horioka (1980) framework relating domestic investment to national saving to also include how this relationship is affected by financial integration. ${ }^{29}$ They find that financial integration appears to benefit investment the most when national saving is weak. ${ }^{30}$ However, at the average national saving rates in Latin American and Caribbean countries today (less than 20 percent of GDP), the investment impact of financial integration is practically nil. Moreover, if greater financial integration is not matched with appropriate policies and regulations to control exposure to macroeconomic risk and these risks escalate, then the net result of the trade-off between more investment and higher risk could even be negative.

The steady advance of financial integration over the past 20 years in the region, coupled with the equally steady increase in the index of 
macroeconomic risk shown in Figure 5.8, is a warning sign. Clearly, more financial integration is beneficial when soundly managed. Even then, however, it is far from a cure. Stronger national saving remains the key to faster and sustainable growth.

\section{Safety First}

Clearly, national and foreign saving are not good substitutes. If national saving falls short of investment needs, at best, foreign saving will fill only part of the gap. Furthermore, the inflow of foreign saving comes with a price tag: it can raise the likelihood of external crises and overall macroeconomic risks. In turn, crises can further deter investment and growth. National saving does not. It is safer, and with no strings attached. Sound policies that promote national saving support faster and more sustainable growth.

Higher national saving reduces the need for importing saving from abroad. This is particularly important for most countries in Latin America and the Caribbean, for whom higher levels of foreign saving represent a crisis risk factor that is again on the rise. A slower accumulation of foreign liabilities would reduce risks, particularly in countries with a riskier composition of liabilities. Even if some national saving moves abroad (in the form of capital outflows), external assets would protect against external crises, especially in countries that invest in safer instruments.

Safety is a virtue, particularly for a region that has been wracked by volatility and macroeconomic crises for the last half century. These gyrations have taken their toll on development and must be controlled if the region is to grow and prosper. National saving is safe and supports stability-a critical factor in an environment conducive to equitable and sustainable development. 


\section{Notes}

1 This chapter draws heavily on Cavallo, Fernández-Arias, and Marzani (2016).

2 Aizenman, Pinto, and Radziwill (2007) show that accumulated national saving represented some 90 percent of the total stock of domestic capital across emerging countries during the 1990's. Similar estimations in Cavallo, Fernández-Arias, and Marzani (2016) confirm the overwhelming importance of national savings in Latin America: the portion of the capital stock that can be accounted by national savings has ranged on average from 90 percent to 105 percent during the past few decades. These measures overestimate the importance of national saving because not all such saving is applied to domestic investment financing. Nevertheless, if capital outflows are fully deducted from national savings to arrive at a lower bound for national financing, the self-financed portion of the capital stock is still predominant (averaging between 70 percent and 80 percent in the last few decades).

3 Even then, as argued by de la Torre and Ize (2015), the absorption of foreign savings would hurt growth by reducing net exports, which is found to be associated with high productivity and growth. In this case, stronger national savings would support growth even under perfect financial integration.

4 The level of investment is not all that counts. Shortcomings in national saving may constrain not only the level of domestic investment but also its quality. Savings that are not efficiently allocated due to domestic distortions lead to the financing of low return investments, which would be reflected in lower aggregate total factor productivity.

5 "National saving" (the unconsumed part of national income) differs from "domestic saving" (the unconsumed part of gross domestic output). The difference between the two is international factor payments. In terms of national accounting, national saving is equal to Investment + current account deficit (foreign saving). Domestic saving is equal to Investment + Trade Balance.

6 For a summary of the discussion on the role of global factors versus domestic factors in driving capital flows to emerging markets, see Calvo, Leiderman, and Reinhart (1996).

7 For example, in Latin America and the Caribbean in the 1980s, the unyielding external debt overhang acted as an implicit tax on 
investment (the fruits of growth would increase countries' capacity to pay and then be captured by external creditors). Perhaps more importantly, it also created deep uncertainty over how the burden of the ultimate costs would be distributed across different economic agents (see Cavallo, Fernández-Arias, and Powell, 2014).

8 See Jeanne and Korinek (2010) and Fernández-Arias, and Lombardo (1998).

9 The study of macroeconomic risks resulting from the absorption of foreign savings opens a policy agenda on how to address these market externalities, including the regulation of the rate of absorption and policies discriminating among types of capital inflows and outflows. The analysis of these financial policy implications is beyond the scope of this chapter.

10 Catão and Milesi-Ferretti (2014) do the statistical analysis using a probit regression model for panel data. On the left-hand side of their regressions is the external crisis indicator variable (a dichotomous variable that takes value zero if there is no crisis, and 1 when there is a crisis), while on the right-hand side (explanatory variables) is the net foreign liabilities (NFL) as a ratio of GDP. The risk of crisis increases sharply as NFL exceeds 50 percent of GDP and whenever the NFL/ GDP ratio rises some 20 percentage points above the country-specific historical mean. The implication is that foreign liabilities are risky and should be kept under control.

11 IMF support is defined as IMF loans at least twice as large as the respective country's quota in the IMF, when all net disbursements are computed from the program's inception to end.

12 In general, economic studies on the negative effect of macroeconomic crises on productivity and growth underscore the adverse effects of short-run macroeconomic instability and output volatility on long-term growth. Crises increase uncertainty, drive away investment, produce social tensions, and permanently reduce productivity and output. See, for example, Ramey and Ramey (1995); Cerra and Saxena (2008); and Blyde, Daude, and Fernández-Arias (2010).

13 The sample consists of 71 countries (including 42 emerging economies, of which 16 are from Latin America and the Caribbean) for the period 1970-2011.

14 The bunching of the crises around specific dates-a phenomenon documented by Calvo, Izquierdo, and Mejía (2004) in their work on Sudden 
Stops-suggests that the prevalence of crises is, to some extent, due to factors that are beyond the control of national authorities.

15 The concept of self-financed capital stock is based on the self-financing ratio introduced by Aizenman, Pinto, and Radziwill (2007). In background work for this book it was measured using three alternative metrics (see Cavallo, Fernández-Arias, and Marzani, 2016).

16 Like in Catão and Milesi-Ferretti (2014) the sample consists of a maximum of 71 countries with annual data for the period 1970-2011. This exercise is based on a slightly smaller sample limited by the availability of information needed to conduct the more detailed statistical analysis used in this chapter. For methodology and extensive robustness checks, see Cavallo, Fernández-Arias, and Marzani (2016).

17 As discussed in Chapters 1 and 2, the correlation between foreign and national savings across countries is consistently negative. The Feldstein-Horioka regressions imply that, despite imperfections in financial integration, increased national saving substantially crowds out foreign saving.

18 See Borio and Disyatat (2011) for a discussion about the role of gross versus net capital flows and the links to external financing.

19 See Cavallo et al., (2015) for an analysis of the implications of two-way gross capital flows for the stability of net flows.

20 See Committee on International Economic Policy and Reform (2012).

21 The data on gross foreign assets and liabilities comes from External Wealth of Nations database.

22 Statistical tests were run to gauge the extent of risk offsetting. In all the specifications the hypothesis of full offset was rejected to favor more than full offset at the 5 percent confidence level. For details, see Cavallo, Fernández-Arias, and Marzani (2016).

23 Fernández-Arias and Hausmann (2001). For a recent survey, see Levy Yeyati and Zúñiga (2015).

24 See Cavallo, Fernández-Arias, and Marzani (2016) for a fuller discussion.

25 Hansen and Wagner (2015) confirm and go beyond this result. They show that FDI liabilities are a particularly safer form of capital inflows when they are substantially based on the retained earnings of multinational corporations. It turns out that retained earnings used to finance domestic investment behave as national saving, and both are components of what the authors call "local savings." From the point of 
view of macroeconomic financial risks, it is as if these companies were in part owned by nationals.

26 The EPVI refers only to the contribution of a country's external portfolio to overall risk. Overall risk also depends on the other factors included in the statistical exercise.

27 Of course, financial integration can have other benefits. For example, fewer impediments to cross-border financing can widen the scope for risk diversification. This discussion focuses on only one of the many benefits of financial integration: the investment response.

28 In addition, financial integration may facilitate capital flight, which would deepen macroeconomic instability in certain circumstances.

${ }^{29}$ Financial integration is captured through two standard measures used in the literature: a) the Chinn-Ito index measuring de-jure financial openness (i.e., lack of formal restrictions to the movement of capital flows across countries); and b) the Lane and Milesi-Ferretti (2007) index of de-facto financial openness (i.e., the sum of foreign assets and liabilities as a share of GDP), which encompasses de-jure considerations concerning financial openness as well as easier financial conditions in the supply of foreign savings.

30 This assumes that national saving remains constant as financial integration deepens. This assumption of no crowding out may be optimistic to the extent that financial integration brings lower domestic interest rates. commons.org/licenses/by-nc-nd/3.0/igo/) and may be reproduced with attribution to the Inter-American Development Bank (IDB) and for any non-commercial purpose. No derivative work is allowed.

Any dispute related to the use of the works of the IDB that cannot be settled amicably shall be submitted to arbitration pursuant to the UNCITRAL rules. The use of the IDB's name for any purpose other than for attribution, and the use of IDB's logo shall be subject to a separate written license agreement between the IDB and the user and is not authorized as part of this CC-IGO license. Note that the link provided above includes additional terms and conditions of the license.

The images or other third party material in this chapter are included in the work's Creative Commons license, unless indicated otherwise in the credit line; if such material is not included in the work's Creative Commons license and the respective action is not permitted by statutory regulation, users will need to obtain permission from the license holder to duplicate, adapt or reproduce the material. 